\title{
Pneumonia caused by coliforms and Pseudomonas aeruginosa
}

\author{
PAUL NOONE AND BOGUMILA T. ROGERS \\ From the Microbiology Department, Royal Free Hospital, London NW3
}

SYNOPSIS The diagnosis and treatment of 20 hospital patients seen in the past year with proven $\frac{\Omega}{0}$ pneumonia caused by coliforms and Pseudomonas aeruginosa are discussed. Predisposing factors and methods for improving laboratory and clinical diagnosis are analysed, the main problem being. to discriminate between genuine pneumonia caused by these organisms and mere contamination of ${ }^{\top}$ sputum samples resulting from colonization of the upper respiratory tract following broad-spectrum chemotherapy.

Overall initial chemotherapy with gentamicin cured $75 \%$ (15 out of 20$)$ of the patients in spite of $\vec{c}$ unfavourable underlying pathology. Where gentamicin was given in adequate dosage, which in practice meant that dose which produced peak serum concentrations of $8 \mu \mathrm{g} / \mathrm{ml}$ or more, the cure $\overrightarrow{ }$ rate was $91 \%$ (11 out of 12). In those patients achieving (measured) peak serum concentrations of $\stackrel{\varphi}{\varphi}$ less than $8 \mu \mathrm{g} / \mathrm{ml}$ the cure rate was only 33\% (4 out of 12). These figures include four patients who? failed to respond to doses of gentamicin producing peak concentrations of $5 \cdot 0-6.0 \mu \mathrm{g} / \mathrm{ml}$ in eachO case. These patients responded promptly to higher doses (or accumulation), producing peak serum concentrations of $8 \mu \mathrm{g} / \mathrm{ml}$ or more and were then cured within three to five days.

Toxicity from gentamicin was not observed in any patient. These results indicate that it is necessary to monitor gentamicin therapy by laboratory assay to ensure adequate dosage and that peak serum $\stackrel{\varrho}{\Rightarrow}$ concentrations of $8 \mu \mathrm{g} / \mathrm{ml}$ or more are significantly correlated with successful treatment of pneumonia $\frac{\hat{3}}{3}$ caused by coliforms and $P$ s. aeruginosa.

There has been a steady increase in the incidence of life-threatening infections with coliform organisms and Pseudomonas aeruginosa over the past few decades (Finland et al, 1959; Du Pont and Spink, 1969). This trend has been associated with the introduction and widespread use of antimicrobial agents (Finland et al, 1971) as well as the survival of many older and debilitated patients in hospital, often undergoing major-risk surgery.

Pneumonia in hospital patients attributable to coliforms and pseudomonas is not uncommon (Lerner, 1974; Noone et al, 1974b). Difficulties in diagnosis can arise because of the very widespread colonization of the upper respiratory tract of hospital patients with coliforms and pseudomonas, especially during treatment with broad-spectrum antimicrobial agents. This results in contaminated sputum specimens and the laboratory isolation of coliforms and pseudomonas where they have no direct pathological significance. There is a tendency

Received for publication 30 December 1975 in some quarters to dismiss all coliforms in the? sputum as contaminants.

Culture techniques which involve straight sampling of sputum are unreliable and do not readily distinguish between commensals, contaminants, and true pathogens. Methods which employ liquefaction, homogenization, and dilution of the sputum allow semiquantitative counts to be performed and, provided the specimen is fresh, true pathogens from $N$ lower respiratory tract will tend to occur in much larger numbers $\left(10^{7}-10^{10}\right.$ organisms $\left./ \mathrm{ml}\right)$ than commensals and contaminants from the throat, mouth, $\omega$ and nose (Percival and Roberts, 1972; Monroe et al, 1969).

We have recently analysed the findings in $20 \AA$ consecutive patients in our hospital over the past ${ }^{?}$ year with pneumonia caused by coliforms and Pseudomonas aeruginosa. Since this condition bears $\frac{\overrightarrow{+}}{\mathrm{D}}$ a high mortality (Gatmaitan et al, 1970) our aim? has been to assess the results of chemotherapy as $\triangle$ well as to clarify those clinical and laboratory criteria which would help in diagnosis. 


\section{Patients and methods}

SPUTUM SPECIMENS

In all patients sputum for culture was obtained at the time of diagnosis by aspiration from the bronchi and lower respiratory tract using sterile tubing, the sputum being caught in a plastic 'trap' and sent fresh for culture.

\section{LABORATORY TECHNIQUES}

Gram films were made and the sputum was cultured by the method of Rawlins (1968) using pancreatintrypsin to liquefy and homogenize the sputum which was cultured in dilutions of 1 in 2 and 1 in $10^{-4}$ on chocolate agar in $10 \%$ carbon dioxide, on blood agar (Southern Group) aerobically, on polymyxin-neomycin-fusidate (PNF) plates (Lowbury et $a l, 1964)$ anaerobically (Gaspak system), and on MacConkey plates. The organisms were identified using the methods and tables of Cowan and Steel (1974). Auramine stains for acid-fast bacilli are made and examined routinely with all specimens of sputum.

Our laboratory methods for cultures have been more fully described elsewhere (Noone et al, 1974a). Sensitivity tests were carried out according to the method of Stokes (1968). Aminoglycoside assay was performed using the urease method which has been validated in routine use in this laboratory Noone et al, 1974b).

\section{PATIENTS}

The 20 patients were all hospitalized and consisted of 11 men and nine women aged 40 to 89 with a mean age of 66 years. Table I summarizes their underlying pathology and those factors which may have been associated with the development of pneumonia.

\section{PREVIOUS CHEMOTHERAPY}

Sixteen of the 20 patients $(80 \%)$ were receiving chemotherapy (mean duration six days) at the time the pneumonia developed. As far as could be ascertained most of the drugs administered were

\begin{tabular}{lr}
\hline Malignant disease & 9 \\
Recent major surgery & 13 \\
Recent anaesthetic & 15 \\
Ventilator & 9 \\
Cytotoxic or immunosuppressive drugs or DXRT & 5 \\
Chronic bronchitis & 5 \\
Congestive cardiac failure & 4 \\
Active peptic ulcer & 6 \\
& Total \\
\hline
\end{tabular}

Table I Underlying pathology and factors predisposing to pneumonia in patients studied

There were also three patients with liver failure, two with cerebrovascular accidents, one with myasthenia gravis, and four with haematological disorders (one each with chronic myeloid leukaemia, lymphoma myeloma and myelofibrosis). being given for 'prophylactic' reasons; 14 were receiving ampicillin or amoxycillin, five flucloxacillin, four cotrimaxazole, and one each sulphonamide, lincomycin, cephalexin, and topical neomycin.

\section{Results}

DIAGNOSIS OF PNEUMONIA

All patients had symptoms of pneumonia with dyspnoea, chest pain (when conscious), signs of consolidation and pyrexia; the great majority had a significant neutrophilia of the peripheral blood. There was fresh radiological evidence of pneumonia and except for one patient with neutropenia, all had purulent sputum, often 'dirty' and usually copious. Some of those with pseudomonas infections had marked greenish discoloration of the sputum.

The site of the pneumonic lesions as shown by $x$-ray is given in table II. In almost half there was a history suggestive of aspiration (virtually all those with right-sided or predominantly right-sided lesions).

The patient with neutropenia had a neutrophil count of less than $100 / \mathrm{mm}^{3}$ at the time he developed pneumonia. His chest $x$-ray revealed marked infiltration of the lung fields and the sputum was 'filthy' although Gram stains showed no pus cells. Gram-negative rods were present in very large numbers and there was a pure growth of Klebsiella aerogenes from the aspirated specimen. As the patient recovered from his episode of neutropenia he began to produce mucopurulent sputum.

In 19 patients Gram films revealed pus cells and profuse numbers of typical coliform Gram-negative rods. Growth in all instances was very heavy (more than $10^{7}$ and even up to $10^{10}$ organisms $/ \mathrm{ml}$ ). Pseudomonas aeruginosa, $\mathrm{Kl}$. aerogenes, and Escherichia coli predominated (see table III). In 18 patients the pathogen was isolated in pure growth while in one patient two organisms, and in another patient three organisms, were isolated. Their pathogenic significance was confirmed in nine patients by the isolation of the same organisms from empyema/effusion samples in five ( 2 Klebsiella, 2 Pseudomonas, 1 Enterobacter) and positive blood cultures in four ( $2 \mathrm{Klebsiella-}$ both cured; 1 Proteus and 1 Pseudomonas-both

\begin{tabular}{llll}
\hline Right Side & Left Side & Bilateral & \\
\hline 3 & 6 & & 11 \\
& & Predominantly & Predominantly \\
& & right & left \\
& 5 & 4
\end{tabular}

Table II Radiological site of consolidation

In all but three patients the pneumonic lesion started in a basal lobe. 


\begin{tabular}{|c|c|c|c|}
\hline Organism & No. of Cases & $\begin{array}{l}\text { No. of } \\
\text { Isolations from } \\
\text { Patients dying }\end{array}$ & Complications \\
\hline Ps, aeruginosa & $\begin{array}{l}12(60 \%) \\
(4 \text { carbenicillin- } \\
\text { resistant) }\end{array}$ & 4 & $\begin{array}{l}1 \text { bacteraemia } \\
\text { (died) } \\
2 \text { empyema } \\
\text { (both cured) }\end{array}$ \\
\hline Kl. aerogenes & $5(25 \%)$ & 1 & $\begin{array}{c}2 \text { bacteraemia } \\
\text { (both cured) } \\
2 \text { empyema } \\
\text { (both cured) }\end{array}$ \\
\hline Esch. coli & $\begin{array}{l}4(20 \%) \\
\text { (1 multiple- } \\
\text { resistant) }\end{array}$ & - & - \\
\hline $\begin{array}{c}\text { Enterobacter } \\
\text { aerogenes }\end{array}$ & 1 & 一 & $\begin{array}{l}1 \text { empyema } \\
\text { (cured) }\end{array}$ \\
\hline Pr. vulgaris & 1 & 1 & 1 bacteraemia \\
\hline
\end{tabular}

Table III Causative organisms

All organisms were fully sensitive to gentamicin by the Stokes' technique.

patients died). Eleven patients had sepsis elsewhere, six with apparently the same organism as that identified as causing pneumonia.

\section{CHEMOTHERAPEUTIC TREATMENT}

As soon as the diagnosis was made all the patients were treated with gentamicin at an initial dosage of 4.5-6.0 $\mathrm{mg} / \mathrm{kg}$ per 24 hours divided into 8-hourly injections. Subsequent dosage depended on the results of serum assay. One patient was changed to ampicillin and another to carbenicillin when the results of sensitivity tests of the pathogens were known. In both instances the patient had already shown a good response to 24 hours' treatment with gentamicin (both had adequate serum concentrations). Of the 20 patients, $15(75 \%)$ were cured. The neutropenic patient also received neutrophil transfusions though he had responded clinically while still neutropenic. Six of the patients who were cured died within one month from underlying pathology but without pneumonia. A further octogenarian died within six months from arteriosclerosis (without pneumonia), but the other patients who were cured were alive and well up to one year later. In all instances those who were cured showed complete recovery both clinically and radiologically. Where sputum continued to be produced it became mucoid and failed to yield the treated pathogen.

Five patients died with pneumonia as a main cause, four receiving an inadequate dosage of gentamicin (table IV).

Of the 12 patients given a dose of gentamicin producing serum concentrations of $8 \mu \mathrm{g} / \mathrm{ml}$ or more, 11 were cured $(91 \%)$ (table IV). The only failure in this group was a 60-year-old man with massive haemorrhage following splenectomy who developed bilateral aspiration pneumonia and bacteraemia

\begin{tabular}{|c|c|c|}
\hline $\begin{array}{l}\text { Highest Peak Serum } \\
\text { Concentration achieved }\end{array}$ & Cures & Failures \\
\hline $\begin{array}{l}8 \mu \mathrm{g} / \mathrm{ml} \text { and }>8 \mu \mathrm{g} / \mathrm{ml} \\
(\mathrm{range} 8-15 \cdot 0 \mu \mathrm{g} / \mathrm{ml}) \\
<8 \mu \mathrm{g} / \mathrm{ml} \\
\text { (range } 3-7 \cdot 0 \mu \mathrm{g} / \mathrm{ml} \text { ) }\end{array}$ & $\begin{array}{l}11(91 \%)^{1} \\
4(33 \%)\end{array}$ & $\begin{array}{l}1 \text { (died) } \\
8(4 \text { died })^{1}\end{array}$ \\
\hline \multicolumn{3}{|c|}{$\begin{array}{l}\text { Table IV Results related to peak serum concentrations } \\
\text { of gentamicin }\end{array}$} \\
\hline \multicolumn{3}{|c|}{$\begin{array}{l}{ }^{1} \text { These figures included the four patients whose details are given } \\
\text { table V. }\end{array}$} \\
\hline
\end{tabular}

with Ps. aeruginosa. After this he suffered severeo hypotension and acute renal failure. He had twe days' inadequate gentamicin therapy (peak con-ĩ centrations up to $3.0 \mu \mathrm{g} / \mathrm{ml}$ ) before his dose was increased and he achieved adequate peak serumos concentrations of $10.5 \mu \mathrm{g} / \mathrm{ml}$. He was then switched to tobramycin at the same dosage but died two days? later from the metabolic complications of his renatfailure (but without bacteraemia).

Of the 12 patients given a dose producing (measured) peak serum concentrations of less thane $8 \mu \mathrm{g} / \mathrm{ml}$, only four (33\%) were cured, these patientsō obtaining highest measured peak serum concentrations of $7.0 \mu \mathrm{g} / \mathrm{ml}, 6.4 \mu \mathrm{g} / \mathrm{ml}, 6.1 \mu \mathrm{g} / \mathrm{ml}$, and $5.2 \mu \mathrm{g} / \mathrm{ml}$ respectively. Of the eight failures, four patients responded only when their gentamicing dosage was increased so as to give peak serump concentrations of $8 \mu \mathrm{g} / \mathrm{ml}$ and more, although on their initial dosage they had peak concentrations of 5-6 $\mu \mathrm{g} / \mathrm{ml}$ (table V).

These results confirm our previous experience (Noone et al, 1974a). In those patients who survived. there was no clinical evidence of ototoxicity. Three patients on completion of treatment underwento special tests, including puretone audiograms and. standard Hallpike Caloric Tests, for evidence of asymptomatic eighth cranial nerve damage. None was discovered. There was no evidence of nephro윽 toxicity in any patient.

\section{Discussion}

DIAGNOSIS OF GRAM-NEGATIVE PNEUMONIA This series suggests that Gram-negative pneumonia should be regarded as a possibility in all patientso who develop pneumonia in hospital. There should be an even higher degree of suspicion in elderly anc otherwise debilitated patients who have recently undergone major surgery or received an anaesthetic, $\square$ particularly where there is a history of respiratory disease, immunosuppression or mechanical venti lation.

In all our patients there was an obvious clinica pneumonia, often developing or getting worse in spite of apparent adequate treatment with cons 


\begin{tabular}{|c|c|c|c|c|c|c|c|}
\hline Sex & $\begin{array}{l}\text { Age } \\
(y r)\end{array}$ & Organism & $\begin{array}{l}\text { Initial Dose } \\
\text { (mg/kg per } 24 \mathrm{hr})\end{array}$ & $\begin{array}{l}\text { Initial Peak } \\
\text { Concentration } \\
(m g / m l)\end{array}$ & $\begin{array}{l}\text { Duration of } \\
\text { this Dosage }\end{array}$ & $\begin{array}{l}\text { Later Dose } \\
(\mathrm{mg} / \mathrm{kg} \text { per } 24 \mathrm{hr})\end{array}$ & Later Peak \\
\hline $\mathbf{M}$ & 67 & Kl. aerogenes & $6 \cdot 0$ & $\begin{array}{l}3 \cdot 2-5 \cdot 0 \\
\text { (5 assays) }\end{array}$ & 5 days & $7 \cdot 0$ & $\begin{array}{l}7 \cdot 9-9 \cdot 4 \\
\text { ( } 4 \text { assays) }\end{array}$ \\
\hline $\mathbf{F}$ & 85 & Ps. aeruginosa & $5 \cdot 0$ & $\begin{array}{l}4 \cdot 4-6 \cdot 0 \\
\text { (3 assays) }\end{array}$ & 4 days & 6.6 & $\begin{array}{l}8 \cdot 3-12 \cdot 0 \\
\text { ( } 4 \text { assays) }\end{array}$ \\
\hline $\mathbf{M}$ & 84 & Ps. aeruginosa & $4 \cdot 5$ & $\begin{array}{l}3 \cdot 3-6 \cdot 1 \\
\text { ( } 2 \text { assays) }\end{array}$ & 3 days & $\begin{array}{l}\text { Same but } \\
\text { accumulation } \\
\text { because of } \\
\text { renal disease }\end{array}$ & $\begin{array}{l}7 \cdot 4-14 \cdot 8 \\
\text { (3 assays) }\end{array}$ \\
\hline $\mathbf{F}$ & 85 & Kl. aerogenes & 6.0 & $\begin{array}{l}\text { 4.4-6.0 } \\
\text { ( } 3 \text { assays) }\end{array}$ & 3 days & $\begin{array}{l}\text { Same but } \\
\text { accumulation }\end{array}$ & $\begin{array}{l}7 \cdot 6-8 \cdot 0 \\
\text { (2 assays) }\end{array}$ \\
\hline
\end{tabular}

Table V Details of four patients responding only to increased serum concentrations of gentamicin

All four patients responded within 24-48 hours of increasing the dose of gentamicin (or its accumulation to adequate concentrations).

ventional antibiotics. A chest $x$-ray revealed confirmatory radiological changes. Sputum aspirated from the lower respiratory tract was copious and offensive and showed large numbers of polymorphs and Gram-negative rods.

The coliform was obtained in a heavy growth of at least $10^{7}$ organisms $/ \mathrm{ml}$ and was repeatedly isolated if further specimens were taken before effective chemotherapy was instituted. In some cases the organisms were also isolated from blood cultures or pus aspirated from empyema or pleural fluid. There was no doubt about the pathogenic role of the organisms isolated.

Although this group of patients all had Gramnegative sepsis, the differential diagnosis included pneumonia caused by other opportunist pathogens such as Staphylococcus aureus, anaerobic cocci, bacteroides, Candida species, and Pneumocystis carinii. The last, however, is usually seen only in this and similar countries in immunosuppressed patients (Minielly et al, 1969). Gram films were of value and full culture was always undertaken, including anaerobic culture.

It is often stated that transtracheal aspiration should be the technique employed to collect sputum and, if feasible, this should bedone, otherwise sputum aspirated from the lower respiratory tract via sterile tubing ('trap' specimens) should be used.

When an homogenization technique is used, 'trap' specimens yield a heavy growth of true pathogens. Contaminants, picked up on the tube when it is passed through the pharynx, will be in very small numbers. It has been suggested that the bubbling of air through 'trap' specimens should not kill most anaerobic organisms (Willis, personal communication). Mitchell and Harvey (1975) have recently described a rapid homogenization and dilution technique for culturing sputum using a Stomacher which enables more accurate quantitative assessment.

There are obvious difficulties in assessing the significance of coliforms and pseudomonas in sputum specimens. Their isolation, even from a purulent specimen, must not lead to antimicrobial treatment for these organisms unless there is genuine evidence that the patient has pneumonia and that the organism is responsible. Over $90 \%$ of coliforms and pseudomonas isolated from sputum represent mere colonization of the oropharynx. In a recent paper (Freeman, 1974) laboratory tests have been described to distinguish between $\mathrm{Kl}$. aerogenes and $K l$. pneumoniae based on the assumption that Klebsiella strains of the $\mathrm{Kl}$. pneumoniae biotype are respiratory pathogens whereas $K l$. aerogenes biotypes are not (Darrell and Hurdle, 1964). This would seem to be a misguided approach; the surest way to judge the pathogenicity of organisms is to see the patient concerned and review all the evidence available (microbiological, clinical, and radiological) in order to arrive at a conclusion about the role of the coliforms in the sputum. In our patients there was incontrovertible evidence that $\mathrm{Kl}$. aerogenes was causing opportunist infection.

\section{OUTCOME OF THERAPY}

Our results are good considering that this is a condition with high mortality. All the treatment failures in our series died with pneumonia as the major cause of death (except those detailed in table V).

The drug of choice for (aerobic) Gram-negative pneumonia is gentamicin or another aminoglycoside with similar antimicrobial spectrum provided adequate dosage is given. In practice the choice of antibiotic is not so difficult because usually the patient is already receiving conventional antibiotics and is deteriorating. The use of assay techniques to monitor dosage is essential with the aim of achieving sufficient blood (and tissue) concentrations.

Our results indicate that peak serum gentamicin concentrations of $8 \mu \mathrm{g} / \mathrm{ml}$ or more are usually necessary to obtain a cure. Physiotherapy and drainage of abscesses (where they develop) is also essential. In most patients chemotherapy was needed for only 7 to 10 days provided adequate dosage was given. In two patients chemotherapy was changed 
as a result of laboratory tests, but in both cases the patient had already responded to gentamicin.

To avoid ototoxicity, trough concentrations of gentamicin were also monitored (Reeves, 1974) from the first day of therapy in patients with renal dysfunction but from the third day, or at the very latest the fifth day, in all other patients. Eight-hour post-dose concentrations greater than $2 \mu \mathrm{g} / \mathrm{ml}$ were taken to indicate accumulation of the drug and the need to modify dosage, usually by increasing the interval between injections. No gentamicin toxicity was seen in any patient.

If Ps. aeruginosa is strongly suspected as the causative organism then carbenicillin may be added to gentamicin with advantage at a dosage of at least $20 \mathrm{~g} / 24$ hours, being stopped if Klebsiella or a carbenicillin-resistant organism is isolated subsequently. Carbenicillin may be contraindicated if the patient has renal, liver or cardiac failure, as overloading with sodium can occur. In neutropenic patients it is probably obligatory to give carbenicillin with gentamicin for treating Pseudomonas infections because of the prolonged killing times required for Pseudomonas, using gentamicin alone, in these patients (Jackson and Riff, 1971).

Tobramycin is an alternative to gentamicin and can be given in similar dosage to achieve the same kind of serum concentrations. It can be used with advantage against those strains of Ps. aeruginosa which show greater susceptibility to tobramycin than to gentamicin. However, tobramycin seems to have less activity against many strains of Klebsiella and is also less active against Staph. aureus (Waterworth, 1972).

\section{PREVENTION}

One of the most striking aspects of our series is that broad-spectrum chemotherapy, in particular ampicillin with or without flucloxacillin, given usually as a general prophylaxis for surgery, radiotherapy, etc, is associated with the development of Gramnegative pneumonia in the elderly and debilitated patient. It would seem wise to avoid non-specific, broad-spectrum prophylaxis and so help prevent colonization of the upper respiratory tract with resistant Gram-negative organisms from the hospital environment. In this way the risk of developing pneumonia with these opportunist pathogens may be minimized.

\section{References}

Cowan, S. T. and Steel, K. J. (1974). Manual for the Identifi- cation of Medical Bacteria, 2nd edition. Cambridge $\stackrel{\stackrel{2}{二}}{\frac{1}{0}}$ University Press, London.

Darrell, J. H. and Hurdle, A. D. F. (1964). Identification and clinical significance of Klebsiella species in chest infections. J. clin. Path., 17, 617-621.

Du Pont, H. L. and Spink, W. W. (1969). Infections due to Gram negative organisms: an analysis of 860 patients with bacteremia at the University of Minnesota Medical Center, 1958-1966. Medicine (Baltimore), 48, 307-332.

Finland, M., Marget, W., and Bartmann, K. (Eds.) (1971). Bacterial Infections: Changes in their Causative Agents, $\infty$ Trends, and Possible Basis (Bayer Symposium III). Springer, $\vec{\nabla}$ New York

Finland, M., Jones, W. F. Jr. and Barnes, M. W. (1959). $\overrightarrow{\vec{\omega}}$ Occurrence of serious bacterial infections since introduction of antibacterial agents. J. Amer. med. Ass., 170, 2188-2197.

Freeman, R. (1974). A simple and rapid method for the iN differentiation of the members of the genus Klebsiella. J. clin. Path., 27, 925-926.

Gatmaitan, B. G., Carruthers, M. M., and Lerner, A. M. ज (1970). Gentamicin in treatment of primary Gram-negative $\mathrm{N}$ pneumonias. Amer. J. med. Sci., 260, 90-94.

Jackson, G. G. and Riff, L. J. (1971). Pseudomonas bacteremia: pharmacologic and other bases for failure of $c$ treatment with gentamicin. $J$. infect. Dis, , 124, S. 185-191.

Lerner, A. M. (1974). In Current Concepts in the Management of Gram Negative Bacterial Infections (International $\vec{\theta}$ Congress Series, 318), edited by A. R. Ronald, pp. 29-35. নৃ Excerpta Medica/American, Elsevier, New York.

Lowbury, E. J. L., Kidson, A., and Lilly, H. A. (1964). A new selective blood agar medium for Streptococcus pyogenes and other haemolytic streptococci. J. clin. Path., 17, 231-235.

Minielly, J. A., Mills, S. D., and Holley, K. E. (1969). ̊ Pneumocystis carinii pneumonia. Canad. med. Ass., J., 100, 846-854

Mitchell, N. J. and Harvey, A. R. (1975). Application of the Stomacher for rapid homogenization of sputum and the serial streak dilution method for quantitative culture. J. clin. Path., 28, 421-423.

Monroe, P. W., Muchmore, H. G., Felton, F. G., and Pirtle, J. K. (1969). Quantitation of microorganisms in sputum. Appl. Microbiol., 18, 214-220.

Noone, P., Parsons, T. M. C., Pattison, J. R., Slack, R. C. B., Garfield-Davies, D., and Hughes, K. (1974a). Experience in monitoring gentamicin therapy during treatment of $\mathrm{O}$ serious Gram-negative sepsis. Brit. med. J., 1, 477-481.

Noone, P., Pattison, J. R., and Garfield-Davies, D. (1974b) The effective use of gentamicin in life-threatening sepsis. Postgrad. med. J., 50, Suppl. 7, 9-16.

Percival, A. and Roberts, C. (1972). Significance of Entero- 을 bacteria and Pseudomonas in sputum. In Microbiology of the Seventies, edited by F. J. Baker, pp. 154-165. Butter- O worths, London.

Rawlins, G. A. (1968). Use of a pancreatin-trypsin solution $\stackrel{N}{\circ}$ for the liquefaction of sputa for routine bacteriological $\mathbb{\omega}$ examination. J. clin Path., 21, 531-532.

Reeves, D. S. (1974). Gentamicin therapy. Brit. J. Hosp. Med., $12,837-850$.

Stokes, E. J. (1968). Antibiotic sensitivity tests. In her Clinical Bacteriology, 3rd edition, pp. 173-185. Edward Arnold, $\stackrel{\mathscr{S}}{+}$ London.

Waterworth, P. M. (1972). The in vitro activity of tobramycin compared with that of other aminoglycosides. J. clin. Path., 25, 979-983. 